\title{
DIAGNOSIS PENYAKIT MOSAIK (SOYBEAN MOSAIC VIRUS) TERBAWA BENIH KEDELAI
}

\author{
Wuye Ria Andayanie \\ Fakultas Pertanian, Universitas Merdeka, Madiun \\ E-mail : wuye_andayanie@yahoo.com.
}

\begin{abstract}
Mosaic disease (Soybean mosaic virus) diagnosis of soybean seed transmission. Soybean mosaic disease is wide spread throughout soybean-growing countries. Incidence of this disease in East Java is caused by Soybean mosaic virus (SMV) and cowpea mild mottle virus (CMMV). This aim of study was to find the etiology of disease at 14-28 days after planting (dap) on soybean. Research was done by observing visual symptoms. Visual symptoms confirmed by infectivity test, serology assay,electron microscopy (EM) and molecular detection. Results from experiment indicated that soybean plants (14-28 dap) with symptom could be detected in infectivity test. Mechanical inoculation with symptomatic leaf extracts produced local lessions on Chenopodium amaranticolor. Positive results were obtained for Madiun, Ngawi, and Magetan samples when tested against antiserum of SMV in serological assay, however Ponorogo samples were not detected by serological assay. Electron microscopy was also done for the selected sample to confirm the result of positive results. In EM observations, characteristic filamentous particles with modal length close to $900 \mathrm{~nm}$ were observed in samples infected with SMV. We detected an array of amplification products of expected size $1385 \mathrm{bp}$ fragment of cylindrical inclusion gene from Madiun, Ngawi, and Magetan isolates in former fields, but not detected in Ponorogo isolate. This result showed the existence of SMV of soybean seed transmission at 14-28 dap in Madiun, Magetan and Ngawi.
\end{abstract}

Key words: Soybean mosaic virus, soybean seed transmitted, polymerase chain reaction, cylindrical inclusion

\section{ABSTRAK}

Diagnosis penyakit mosaik (Soybean mosaic virus) terbawa benih kedelai. Penyakit mosaik kedelai tersebar luas di negara penanam kedelai. Kejadian penyakit ini di Jawa Timur disebabkan oleh Soybean mosaic virus (SMV) dan Cowpea mild mottle virus (CMMV). Tujuan penelitian untuk mengetahui etiologi penyakit kedelai pada 14-28 hari setelah tanam (hst). Penelitian dilakukan dengan mengamati gejala visual. Gejala tersebut dikonfirmasi dengan uji infektivitas, ujiserologi, mikroskop elektron (EM), deteksi molekular. Hasil dari penelitian menunjukkan bahwa tanaman kedelai bergejala (14-28 hst) dapat dideteksi dengan uji infektivitas. Inokulasi secara mekanik dengan ekstrak daun bergejala menghasilkan becak lokal pada Chenopodium amaranticolor. Sampel dari Madiun, Ngawi, dan Magetan menghasilkan reaksi positif pada uji serologi dengan antiserum SMV, walaupun sampel dari Ponorogo tidak terdeteksi dengan uji serologis. Sampel-sampel yang bereaksi positif tersebut dikonfirmasi dengan pengamatan mikroskop elektron (EM). Pengamatan EM, karakteristik partikel berbentuk batang lentur dengan panjang artikel $900 \mathrm{~nm}$ yang diamati dalam sampel terinfeksi. Produk amplifikasi gen Cylindrical inclusion fragmen DNA dari isolat Madiun, Ngawi, dan Magetan mempunyai ukuran 1385bp, tetapi fragmen DNA tersebut tidak terdeteksi di isolat Ponorogo. Hasil ini menunjukkan tanaman14-28 hst terinfeksi SMV di Madiun, Magetan, dan Ngawi ditularkan lewat benih.

Kata kunci: Soybean mosaic virus, terbawa benih kedelai, polymerase chain reaction, cylindrical inclusion.

\section{PENDAHULUAN}

Produksi kedelai di Indonesia tahun 2012 diperkirakan turun 8,40\% dibandingkan tahun 2011. Penurunan produksi ini terutama dialami oleh Jawa Timur, Nusa Tenggara Barat, Jawa Barat, Sumatera Utara, dan Lampung (BPS, 2012). Salah satu penyebab rendahnya produktivitas kedelai adalah serangan penyakit mosaik kedelai. Di Jawa Timur, penyakit mosaik kedelai terutama disebabkan oleh Cowpea mild mottle virus (CMMV) dan Soybean mosaic virus (SMV) (Saleh \& Baliadi, 2006; Andayanie et al., 2011). SMV adalah virus yang ditularkan melalui benih. Sistem perbenihan kedelai di Indonesia yang masih kurang sempurna mempengaruhi penularan dan penyebaran penyakit mosaik (Saleh, 2007). Benih terinfeksi SMV berperan sebagai sumber inokulum (primary source of infection). Sumber inokulum ini mempunyai peranan 
dalam penularan dan penyebaran penyakit oleh serangga vektor di lapangan. Virus tersebut menghasilkan gejala biji mottle (burik) dan non-mottle. Oleh karena itu biji non-mottle tidak dapat dijadikan jaminan bebas SMV. Infeksi virus pada biji dapat menyebabkan viabilitas atau daya tumbuh benih rendah. Virus ini akan aktif setelah benih disemaikan dan menyebabkantanaman terinfeksi. Infeksi SMV pada awal pertumbuhan akan menghasilkan produktivitas yang semakin rendah.Infeksi virus ini dapat menurunkan produktivitas $25,48 \%$ sampai $93,84 \%$. Hasil penelitian menunjukkan intensitas penyakit pada awal pertumbuhan mencapai 13,42 - 30,10\% (Koning \& Te Krony, 2003; Hobbs et al., 2003; Andayanie, 2012a).

Infeksi SMV menyebabkan gejala pada tanaman, seperti daun permukaannya tidak rata, mengecil dengan gambaran mosaik, menggulung ke dalam, dan tepi daun mengalami klorosis, kadang-kadang disertai tanaman menjadi kerdil. Gejala mosaik pada daun dan gejala burik pada biji tidak dapat digunakan untuk menyimpulkan bahwa daun dan biji tersebut terinfeksi SMV. Uji serologi menunjukkan biji terinfeksi SMV tidak semua memperlihatkan gejala mottle. Biji mottle dapat dihasilkan oleh biji sehat (Andayanie, 2012b). Tanaman sehat dapat menghasilkan biji dengan intensitas mottle yang lebih tinggi pada suhu $20^{\circ} \mathrm{C}$ dibandingkan suhu $30^{\circ} \mathrm{C}$. Suhu rendah akan mempengaruhi ekspresi gen di hilum. Oleh karena itu, uji infektivitas pada tanaman indikator diperlukan untuk mengetahui gejala luka nekrotik terhadap SMV (Tavasoli et al., 2009; Arif \& Hasan, 2000; Andayanie et al., 2011). Pengamatan gejala dan uji serologi yang di ikuti oleh pengamatan mikroskop elektron dilakukan untuk mengetahui partikel nukleoprotein virus yang menginfeksi tanaman. Partikel nukleoprotein SMV mempunyai bentuk batang lentur (filamentous) dengan ukuran panjang 650"900 nm dan diameter 11-13 nm (Chen et al., 2001; Chen et al., 2002). Di Korea ditemukan lima strain SMV yaitu strain G2, G5, G5H, G7, dan G7H. Strain-strain virus tersebut diidentifikasi melalui gejala fenotip dari differential host (inang diferensial). Meskipun pada kondisi lingkungan tertentu gejala penyakit tidak dapat diekspresikan. Sehingga identifikasi strain-strain tersebut juga dilakukan melalui Reverse-transcriptase polymerase chain reaction/restriction fragment length polymorphism (RT-PCR/RFLP) dan dianalisis dengan daerah yang mengkode Cylindrical Inclusion (CI). Sepasang primer CI mengamplifikasi fragmen DNA berukuran $1385 \mathrm{bp}$ pada posisi 4176 sampai 5560 (Kim et al., 2004; Hwang et al., 2011).

Penelitian bertujuan untuk mendiagnosis gejala mosaik pada kedelai di empat kabupaten di Jawa
Timurpada 14-28 hst. Data dan informasi tentang diagnosis SMV terbawa benih digunakan sebagai bahan pertimbangan untuk melaksanakan pengendalian SMV di lapangan dan penelitian yang serupa serta memberikan informasi bagi yang membutuhkan.

\section{METODE PENELITIAN}

Waktu dan Tempat. Penelitian di lapangan dilaksanakan pada bulan Mei 2010 dan dilakukan pada 32 lokasi pertanaman kedelai varietas Wilis milik petani di Kabupaten Madiun, Magetan, Ponorogo dan Ngawi. Daerah tersebut merupakan lumbung kedelai untuk wilayah barat dari Jawa Timur. Setiap kabupaten ditentukan empat desa. Desa tersebut mempunyai areal terluas untuk penanaman benih kedelai. Pemilihan dua hamparan tanaman kedelai dilakukan secara acak di setiap desa. Setiap hamparan mempunyai luas areal tanam kedelai $\pm 5000 \mathrm{~m}^{2}$. Pengambilan contoh tanaman dilakukan pada titik diagonal, masing-masing titik diagonal \pm 100 tanaman (Maugh, 2007).

Penelitian di rumah kaca dan laboratorium Virologi Fakultas Pertanian Universitas Gadjah Mada Yogyakarta dan Fakultas Kedokteran Universitas Airlangga Surabaya dilaksanakan mulai bulan September 2010 sampai bulan Januari 2012. Penelitian ini terdiri atas: uji infektifitas, serologi, pengamatan mikroskop elektron dan deteksi secara molekular.

Pengamatan Gejala Penyakit. Pengamatan gejala penyakit pada tanaman kedelai terdiri atas: gejala awal pada daun muda yang baru tumbuh dan daun yang telah tumbuh sempurna. Gejala tersebut dikelompokkan berdasarkan variasi gejala yang nampak.

Uji Infektivitas. Uji infektivitas dilakukan untuk mengetahui keberadaan dan penyebab penyakit pada tanaman C. amaranticolor. Sumber inokulum diperoleh dari contoh tanaman bergejala pada daun muda yang baru tumbuh dan daun yang telah tumbuh sempurna. Daun kedelai bergejala ditambahkan 0,06 M bufer fosfat $\mathrm{pH} 7$ dengan perbandingan $1 \mathrm{~g}$ daun setiap $10 \mathrm{ml}$ bufer fosfat $(1: 10 \mathrm{~b} / \mathrm{v})$ sebagai larutan ekstrak daun sakit. Larutan tersebut diambil cairan perasan dengan kapas steril. Tanaman C. amaranticolor pada daun ke tiga ditaburi dengan carborundum 600 mesh di bagian permukaan atas daun, selanjutnya bagian tersebut dibersihkan dengan air steril. Setengah bagian dari helai daun diinokulasi dengan cairan perasan tersebut. Setiap ulangan diambil tiga tanaman dengan tiga kali ulangan. Tanaman dipelihara dalam kotak kasa yang tidak terlalu gelap dan panas akan mendukung munculnya gejala 
nekrotik terhadap infeksi virus yang diuji. Tanaman akan menampakkan gejala becak lokal setelah 15 hari inokulasi. Becak tunggal diinokulasikanke tanaman kedelai untuk mengetahui penyebab penyakit dan gejala pada tanaman kedelai.

Uji Serologi. Uji serologi dilakukan dengan metode non-precoated indirect ELISA Menurut Koenig (1981) yang telah dimodifikasi. Uji tersebut menggunakan contoh daun bergejala mosaik, sehat di masing-masing lokasi. Contoh daun diekstraksi dengan bufer Nakarbonat $\mathrm{pH}$ 9,6. Ekstrak tersebut disiapkan dengan seri pengenceran $10^{-2}$ untuk memperoleh antigen. Antigen dimasukkan ke dalam lubang sumuran ELISA plate sebanyak $150 \mu \mathrm{l}$ dan diinkubasi pada suhu kamar selama dua jam. Setelah inkubasi, sap dibuang dan microtitre plate dicuci dengan PBST sebanyak tiga kali, kemudian dimasukan $100 \mu \mathrm{l}$ (BSA) 2\% dan diinkubasi selama dua jam pada suhu ruang. Sap dibuang dan platedicuci dengan PBST sebanyak tiga kali, kemudian dimasukkan $100 \mu \mathrm{l}$ antiserum (diencerkan $10^{-3}$ ) serta diiinkubasi pada suhu $37^{\circ} \mathrm{C}$ selama dua jam. Sap dibuang dan dicuci sebanyak tiga kali dengan larutan PBST, selanjutnya kedalam masing-masing sumuran dimasukkan atau bloking dengan substrat (p-nitrophenil phosphate $1 \mathrm{mg} / \mathrm{ml}$ dalam $10 \%$ diethanolamine $\mathrm{pH} 9,8$ ) sebanyak $100 \mu \mathrm{l}$ dan diinkubasi selama 1,5 jam pada suhu $27^{\circ} \mathrm{C}$. Reaksi yang terjadi diamati dengan ELISA reader pada panjang gelombang $405 \mathrm{~nm}$. Reaksi dihentikan dengan cara ditambahkan larutan $\mathrm{NAOH}$ ke dalam masing-masing sumuran.

Pengamatan Mikroskop Elektron. Pengamatan ini bertujuan untuk mengamati morfologi nukleoprotein (virus). Sediaan virus yang digunakan dari daun kedelai bergejala pada 14-28 Hst dan bereaksi positif dengan uji serologi. Pengamatan ini dilakukan dengan cara Dijkstra \& de Jager (1998). Grid yang mempunyai ukuran 400 mesh dilapisi dengan Carbon-formvar. Grid tersebut disentuhkan ke daun terinfeksi. Selanjutnya membran parafilm ditetesi dengan $\mathrm{ddH}_{2} \mathrm{O}$, dan dilakukan coating dengan grid tersebut selama dua menit. Grid diserap dengan kertas filter yang berbentuk potongan segitiga. Grid ditetesi dengan larutan $2 \%$ Phosphotungtic acid (PTA) pH 6,5 selama 15 detik. Grid dikeringkanlagi dengan kertas filter dan Grid dimasukkan ke mikrokop elektron (JEOL 100S Electron Microscope (EM) (JEOL Ltd., Tokyo, Japan) untuk pengamatan nukleoprotein atau virus.

Deteksi Molekular. Ekstraksi RNA total menggunakan contoh daun kedelai bergejala. Selanjutnya prosedur mengikuti rekomendasi perusahaan (Qiagen). Jaringan tanaman yang terinfeksi ditimbang $(0,1 \mathrm{~g})$ dan ditambahkan nitrogen cair $(2000 \mu \mathrm{l})$ kemudian dilakukan penggerusan. Bubuk jaringan tanaman dimasukkan ke tabung ependorf dan ditambahkan bufer RLT $(450 \mu \mathrm{l})$, serta ditambahkan mercaptoethanol $(4,5 \mu \mathrm{l})$, kemudian dilakukan homogenisasi. Selanjutnya larutan dipindahkan ke spin column warna lila dan disentrifugasi $14.000 \mathrm{rpm}$ selama dua menit, larutan tersebut ditambahkan etanol(96-100\%) setengah dari volume total. Larutan dicampur segera dengan pipeting. Larutan dipindahkan ke spin column yang merah muda, kemudian disentrifugasi $12.000 \mathrm{rpm}$ selama 50 detik dengan suhu $22^{\circ} \mathrm{C}$, selanjutnya supernatan dibuang. Pelet ditambahkan dengan bufer RW1 $(700 \mu 1)$ dan disentrifugasi $12.000 \mathrm{rpm}$ selama 50 detik dengan suhu $22{ }^{\circ} \mathrm{C}$, supernatan dibuang. Pelet ditambahkan dengan bufer RPE $(500 \mu \mathrm{l})$ dan disentrifugasi $12.000 \mathrm{rpm}$ selama15 detik, supernatan dibuang dan diulangi tetapi dengan waktu dua menit, supernatan dibuang. Spin column warna merah muda ditempatkan di tabung dan ditambahkan RNase free water $(50 \mu \mathrm{l})$, kemudian disentrifugasi $12.000 \mathrm{rpm}$ selama satu menit. Cairan yang ada di tabung selanjutnya digunakan sebagai RNA templet untuk keperluan Reverse-transcriptase polymerase chain reaction (RT-PCR).

Reaksi RT-PCR menggunakan First Strand cDNA Synthesis Kit. Semua bahan yang dicampur terdiri atas $5 \mu 1$ RNAse free water, $1 \mu 1 d N T P$ mix, $1 \mu 1$ primer poly $\mathrm{d}(\mathrm{T}), 3 \mu 1 \mathrm{RNA}$ template, sehingga jumlah totalnya $10 \mu \mathrm{l}$. Semua larutan dimasukkan ke mesin thermocycler dan diprogram pada suhu $65^{\circ} \mathrm{C}$ selama lima detik, selanjutnya dimasukkan dalam kotak es. Bahan tersebut dicampur dengan 4,5 $\mu 1$ RNA s free water, $4 \mu \mathrm{l}$ Bufer $5 x$ prime script, 0,5 $\mu 1$ RNAse inhibitor, $1 \mu \mathrm{l}$ RT ensim, sehingga jumlah total $20 \mu \mathrm{l}$. Semua larutan tersebut dimasukkan ke mesin thermocycler, dan diprogram pada suhu $42^{\circ} \mathrm{C}$ selama 60 menit, $95^{\circ} \mathrm{C}$ selama lima menit, $4^{\circ} \mathrm{C}$ tidak terhingga.

Reaksi PCR menggunakan Maxima ${ }^{T M}$ Hot Start Taq DNA Polymerase. Prosedur kerja mengikuti rekomendasi perusahaan (Fermentas). Semua bahan yang terdiri atas $8,5 \mu 1$ water nuclease free, $5 \mu 1$ bufer 10 x Hot Start PCR, $4 \mu 125 \mathrm{mM} \mathrm{MgCl}, 2,5 \mu \mathrm{l} d N T P$ mix $2 \mathrm{~mm}$, Hot Start Taq DNA Polymerase, 1,5 $\mu 1$ Primer CI F(5'GCATTCAACTGTGCGC TTAAAGAAT 3') dan 1,5 il Primer CI R (5'TTGAGGCTGCAAAAATTA CTCACTT 3') (Kim et al., 2004), 2 il DNA template dicampur dengan spindown. Semua larutan dimasukkan ke mesin thermocycler yang diprogram denaturasi awal pada $95^{\circ} \mathrm{C}$ selama dua menit, denaturasi $95^{\circ} \mathrm{C}$ selama satu menit dan annealing (penempelan primer) $68^{\circ} \mathrm{C}$ 
selama satu menit serta ekstensi pada $72^{\circ} \mathrm{C}$ selama satu menit untuk amplification (pelipat gandaan) sebanyak 40 siklus, ekstensi terakhir $72^{\circ} \mathrm{C}$ selama 10 menit dan $4^{\circ} \mathrm{C}$ selama tidak terhingga.

Larutan untuk elektroforesis terdiri atas $7,4 \mathrm{ml}$ distillated water, $1 \mathrm{ml} 10 \times \mathrm{TBE}, 100 \mu \mathrm{APS} 10 \%, 9 \mu 1$ TEMED, 1,7 ml polyacrilamide 29:1. Semua larutan dimasukkan plate dan diberi sisir sebanyak jumlah sampel. Sisir diambil dan plate dimasukkan pada kotak yang telah diberi TBE 1x, kemudian dilakukan loading dengan $3 \mu 1$ sampel dan $2 \mu 1$ pewarna, serta $1 \mathrm{~kb}$ penanda DNA yang digunakan sebagai alat pengukur band. Listrik dipasang dengan 10 MA selama 15 menit, setelah itu dirubah menjadi 24 MA selama 35 menit. Pengamatan dilakukan di bawah transluminator.

\section{HASIL DAN PEMBAHASAN}

Gejala Penyakit. Hasil pengamatan pada tahapan kajian lapangan menunjukkan gejala penyakit pada tanaman kedelai tersebar di semua lokasi pertanaman kedelai sejak awal pertumbuhan. Gejala di lapangan menampakkan keanekaragaman. Infeksi virus penyebab penyakit dapat dibedakan dengan virus lain dengan pengamatan gejala pada saat awal pertumbuhan. Gejala penyakit pada tanaman kedelai setelah melewati awal pertumbuhan sulit dibedakan dengan infeksi virus lain karena gejalanya menjadi kompleks. Keanekaragaman gejala pada tanaman kedelai pada 14-28 hst disajikan pada Gambar 1.
Gejala penyakit pada14-28 hst menunjukkan kecenderungan infeksi virus melalui benih karena gejala muncul seja awal pertumbuhan. Meskipun setelah 28 hst terdapat bersama-sama dengan CMMV (komunikasi pribadi dengan Tomohde Natsuaki, 2010). Secara umum virus yang sama dapat menghasilkan gejala yang berbeda atau gejala yang sama dapat disebabkan oleh virus yang berbeda, sehingga tidak semua gejala mosaik kedelai disebabkan oleh SMV. Keanekaragaman gejala ini disebabkan oleh umur tanaman dan lingkungan saat terjadinya infeksi, virus terbawa benih dan sumber inokulum lain yang menghasilkan gejala yang beranekaragam di lapangan dan juga sering dikacaukan dengan gejala penyakit fisiologis karena kekurangan unsur hara (Hull, 2002). Oleh karena itu, gejala secara visual ini perlu didukung dengan diagnosis serologi, uji infektivitas pada tanaman $C$. amaranticolor, dan pengamatan mikroskop elektron, serta deteksi secara molekular.

Uji Infektifitas. Sampel tanaman dari berbagai lokasi memberikan reaksi berupa gejala becak lokal terhadap infeksi virus pada tanaman indikator (C. amaranticolor) (Gambar 2). Gejala yang dihasilkan ini untuk membedakan dengan gejala penyakit karena kekurangan unsur hara. Meskipun CMMV juga menghasilkan becak lokal pada tanaman indikator tersebut. Oleh karena itu, uji infektifitas ini dikonfirmasi dengan uji serologi.

Uji Serologi. Uji serologi menggunakan metode nonprecoated I-ELISA dengan pelacak antibodi poliklonal
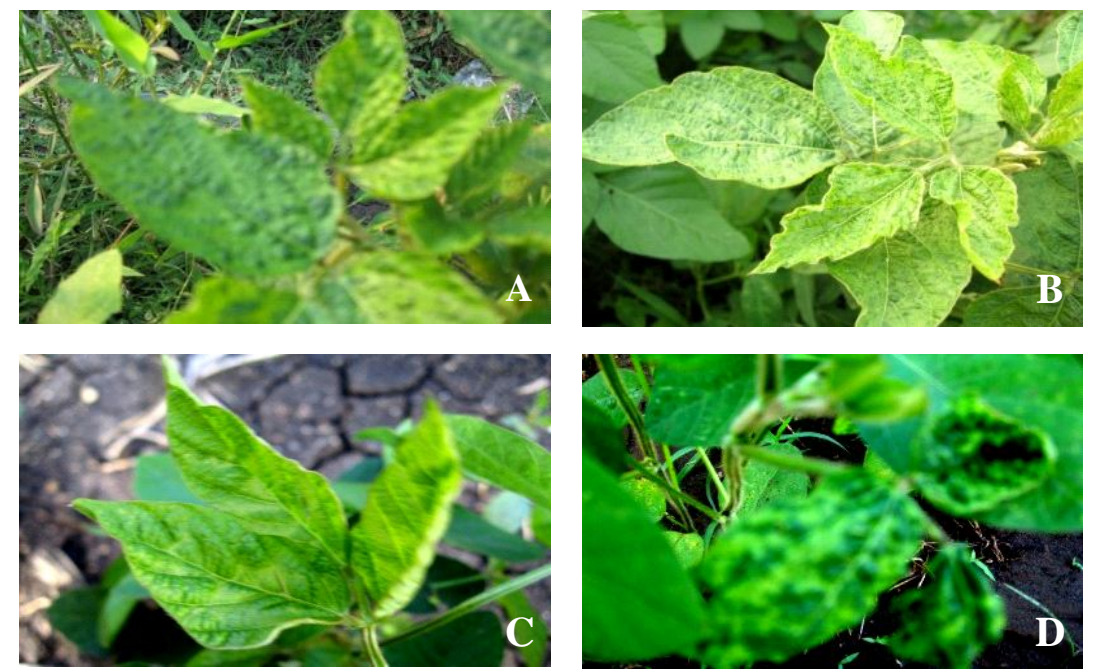

Gambar 1. Keanekaragaman gejala mosaik pada tanaman kedelai 14-28 hst. (A) Daun mengecil, klorosis, dan permukaan daun tidak merata, (B) daun mengecil dan tepi daun melengkung, (C) klorosis dan tulang daun menebal, dan (D) daun mengecil, melengkung ke dalam dan keluar serta melepuh. 
terhadap SMV menunjukkan penyebab penyakit dari gejala yang beranekaragam pada tanaman kedelai pada 14-28 hst bereaksi positif, kecuali di Kabupaten Ponorogo. Hasil uji serologi pada sampel daun tersebut disajikan pada Tabel 1.

Ekstrak tanaman bergejala mosaik menghasilkan nilai dua kali atau lebih besar daripada kontrol negatif pada absorbansi ultraviolet dengan panjang gelombang $405 \mathrm{~nm}$ untuk reaksi antibodi dengan antigen. Hasil uji ini membuktikan gejala penyakit pada contoh tanaman kedelai pada 32 lokasi di Kabupaten Madiun, Magetan, dan Ngawi pada 14-28 hst bereaksi positif dengan antibodi poliklonal terhadap SMV. Sedangkan contoh dari Kabupaten Ponorogo bereaksi negatif. Reaksi positif tersebut dapat dihasilkan oleh virus lain. Hal ini disebabkan antibodi poliklonal SMV yang tidak murni. Hasil penelitian pendahuluan menghasilkan konsentrasi suspensi virus murni adalah $0,7142 \mathrm{mg} / \mathrm{ml}$, sehingga pada setiap 10 gram daun hanya menghasilkan $0,30607 \mathrm{mg}$ virus. Sehingga spesifitas antibodi rendah. Oleh karena itu, reaksi positif dari uji serologi ini dikonfirnasi dengan pengamatan mikroskop elektron.
Pengamatan Mikroskop Elektron. Hasil pengamatan menunjukkan partikel nukleoprotein (virus) berbentuk batang lentur (filamentous) dan panjang berukuran $900 \mathrm{~nm}$ serta diameter sekitar $12 \mathrm{~nm}$. Partikel tersebut merupakan partikel nukleoprotein virus (Gambar 3). Partikel nuleoprotein dengan bentuk dan kisaran panjang serta diameter tersebut termasuk partikel nukleoprotein dari SMV ( Chen et al., 2001 dan Chen et al., 2002)

Deteksi Molekular. Ekstraksi RNA total menggunakan tanaman kedelai bergejala pada 14-28 hst. Fragmen DNA hasil amplifikasi dengan primer CI 5560R dan CI 4176F mempunyai ukuran 1385 bp (Gambar 4 A). Berdasarkan fragmen DNA hasil amplifikasi dengan primer CI 5560R dan CI 4176F menunjukkan pada tanaman kedelai bergejala dari isolat asal Madiun dan Ngawi serta Magetan ditemukan SMV. Fragmen DNA hasil amplifikasi dengan primer CI 5560R dan CI 4176F berukuran 1385 bp mempunyai kesamaan dengan fragmen DNA dari SMV di Korea (Kim et al., 2004).

Fragmen DNA yang tidak berhasil diamplifikasi dengan primer CI 5560R dan CI 4176F dari isolat asal

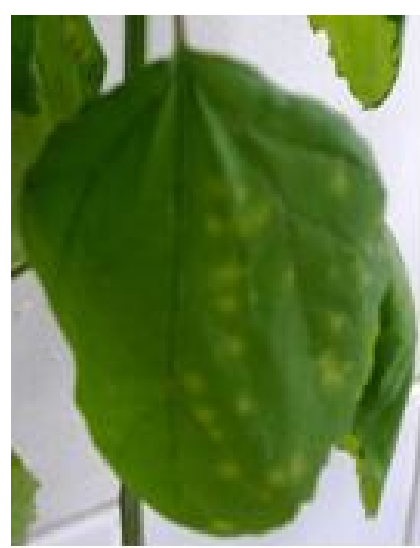

Gambar 2. Gejala becak lokal pada tanaman C. amaranticolor

Tabel 1. Uji serologi pada tanaman kedelai bergejala pada 14-28 hst

\begin{tabular}{lcc}
\hline \multicolumn{1}{c}{ Lokasi } & Rerata nilai absorbansi $\left.\left(\mathrm{A}_{405 \mathrm{~nm}}\right)^{*}\right)$ & Keterangan \\
\hline Ponorogo & 0,350 & - \\
Madiun & 0,932 & + \\
Magetan & 0,963 & + \\
Ngawi & 0,989 & + \\
Daun sehat & 0,224 & \\
Bufer & 0,219 & \\
\hline
\end{tabular}

\footnotetext{
${ }^{*}$ rerata dari 3 ulangan, masing-masing 10 contoh daun, nilai negatif $: \leq 0,438$ (dua kali nisbah bufer).
} 


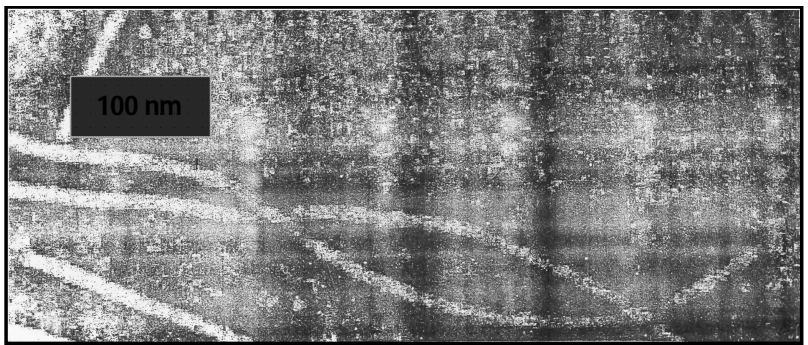

Gambar 3. Partikel nukleoprotein virus. Bar dalam micrograph $100 \mathrm{~nm}$.
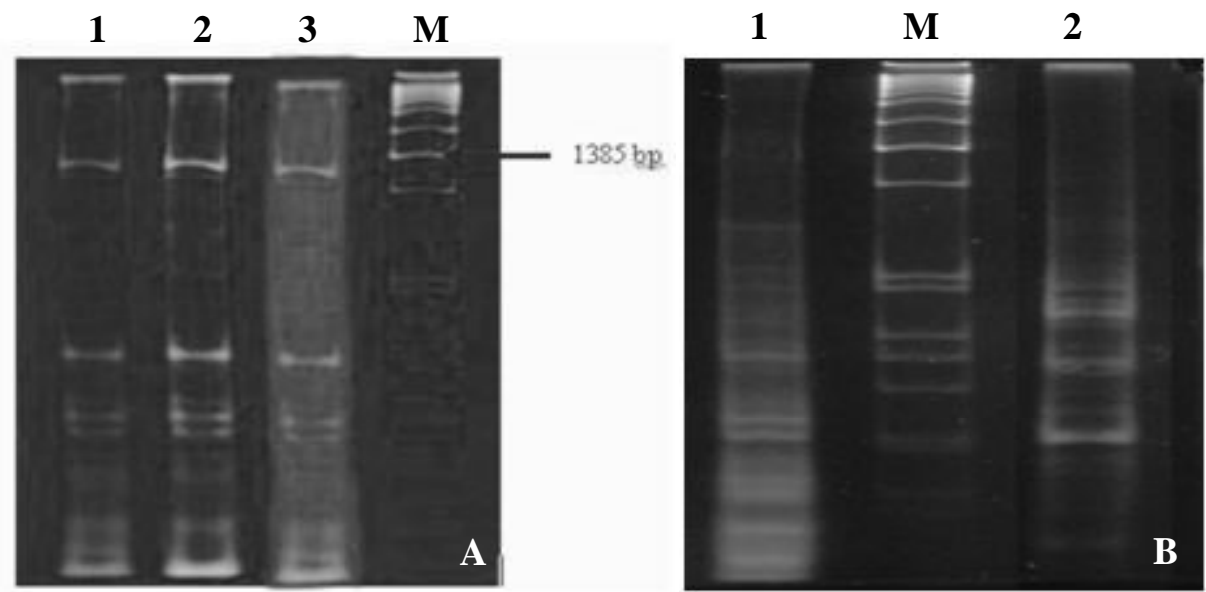

Gambar 4. Fragmen DNA hasil amplifikasi RT-PCR menggunakanprimer CI 5560R dan CI 4176F. (A) Lajur 1. isolat asal Madiun; 2. isolat asal Ngawi; 3. isolat asal Magetan. (B) Lajur 1. isolat asal Ponorogo yang tidak teramplifikasi; Lajur 2. isolat dari tanaman sehat (kontrol M: DNA Ladder $1 \mathrm{~kb}$ sebagai penanda DNA (Fermentas).

Ponorogo (Gambar 4 B). Reaksi negatif dari contoh tanaman bergejala mosaik dapat disebabkan karena infeksi virus lain.

\section{SIMPULAN}

Gejala yang beraneka ragam dihasilkan oleh tanaman kedelai pada 14-28 hst di Kabupaten Madiun, Magetan, Ponorogo dan Ngawi. Uji infektifitas dan serologi menunjukkan gejala tersebut disebabkan oleh penyebab penyakit. Meskipun isolat dari Kabupaten Ponorogomenunjukkan reaksi negatif dengan antibodi poliklonal terhadap SMV. Penyebab penyakit pada tanaman kedelai di Kabupaten Madiun, Magetan, dan Ngawi mempunyai partikel nukleoprotein berbentuk batang lentur dengan panjang berukuran $900 \mathrm{~nm}$ dan diameter berukuran sekitar $12 \mathrm{~nm}$. Isolat tersebut menghasilkan fragmen DNA hasil amplifikasi RT-PCR dengan primer CI 5560R dan CI 4176F berukuran 1385 bp.

\section{SANWACANA}

Penulis mengucapan terimakasih kepada Direktorat Jenderal Pendidikan Tinggi Departemen Pendidikan Nasional Nomor: 096/SP2H/DP2M/IV/2009 dan Nomor: 336/BAP/DP2M/IX/2010. Penulis juga menyampaikan terimakasih kepada Prof (Ret). Dr. Y.B. Sumardiyono, Dr. Sedyo Hartono, M.P., Prof. Dr. Prapto Yudono, M.Sc. (UGM Yogyakarta), Prof. Dr. Tomohide Natsuaki (Director, Center for Bioscience Research and Education Utsunomiya University, Mine-Machi, Japan) yang telah memberikan kritik, saran, fasilitas laboratorium dan analisis untuk diagnosis molekular. 


\section{DAFTAR PUSTAKA}

Andayanie WR, Sumardiyono YB, Hartono S \& Yudono P. 2011. Incidence of soybean mosaic disease in East Java Province. J. Agrivita. 33(1):15-22.

Andayanie WR. 2012a. Penyakit mosaik kedelai dan pengelolaan Soybean mosaic virus terbawa benih. Hlm. 335-347. Dalam: Prosiding Seminar Nasional Hasil Penelitian Tanaman Aneka Kacang dan Umbi. Pusat penelitian dan Pengembangan Tanaman Pangan. Badan Penelitian dan Pengembangan Pertanian, Bogor.

Andayanie WR. 2012b.Evaluation of low temperature treatment induced mutant of Soybean mosaic virus (SMV) for cross protection in soybean. $J$. Australasian Plant Pathology. (Submitted).

Arif M \& Hassan S. 2000. Occurrence and distribution of soybean mosaic potyvirus in soybean crop of North West Frontier Province, Pakistan and characterization of prevalent isolates. Pakistan Journal of Biological Science 3 (12): 21262130.

BPS. 2012. Produksi Kedelai Tahun 2012. Badan Pusat Statistik, Jakarta. http://www.bps.go.id/ brs_file/aram_2jul12.pdf. Diakses tanggal 16 Februari 2012.

Chen J, Chen JP \& Adam MJ. 2001. A universal PCR primer detect members of the Potyviridae and its use to examine the taxonomic status of several members of the family. Journal Archives of virology (arch. virol.). 146: 757-766 p.

. 2002. Characterisation of Some Carla-and Potyviruses from Bulb Crops in China. Journal Archives of Virology.147: 419-428.

Dijkstra J \& de Jager CP de. 1998. Practical Plant Virology: Protocols and Exercises. Springer, London.

Hobbs HA, Hartman GL, Wang Y, Hill CB, Bernard RL, Pedersen WL \& Domier DL. 2003.
Occurrence of seed coat motling in soybean plants inoculated with bean pod mottle virus and Soybean mosaic virus. J. Plant Disease 87: 1333-1335.

Hull, R. 2002. Matthews' Plant Virology. Fourth edition. Academic Press, Tokyo.

Hwang TY, Soon CJ, Oksun K, Hyang MP, Seuk KL, Min JS, Man SC, Yu YL, Hpng TY, Young UK, Wook HK \& Yul HK. 2011. Intra host competition and interaction between Soybean mosaic virus (SMV) strains in mixed infected soybean. Australian Journal of Crop Science 5(11): 1379-1387.

KimYH, Kim OS, Roh JH,Moon JK, Sohn SI, Lee C \& Lee JY.2004. Identification of soybean mosaic virus strains by RT-PCR analysis of cylindrical inclusion coding region. Plant Disease 88: 641645.

Koenig R. 1981. Indirect ELISA methods for the broad specificity detection of plant viruses. J. Gen Virol. 55:53-62.

Koning G \&Te Krony DM. 2003. Soybean seed coat mottling:Association with soybean mosaic virus and Phomopsis spp. seed infection. J. Plant Disease 87: 413-417.

Maugh TM. 2007. Pedoman Surveilensi Organisme Pengganggu Tumbuhan di Asia dan Pasifik. Diterjemahkan oleh Andi Trisyono. ACIAR Monograph No. 119a.

Saleh N \& Baliadi Y. 2006. Penyakit cowpea mild mottle virus pada kedelai dan strategi pengendaliannya. Bul. Palawija. 11: 7-14.

Saleh N. 2007. Sistim produksi kacang-kacangan untuk menghasilkan benih bebas virus. J. Iptek Tanaman Pangan 2 (1): 56-78.

Tavasoli M, Shahraeen N \& Ghorbani SH. 2009. Serological and RT-PCR detection of cowpea mild mottle Carla virus infecting soybean. $J$. General and Molecular Virology 1(1): 7-9. 